\title{
Determinants of the Adoption of Quality Protein Maize among Farming Households in Niger State, Nigeria
}

\author{
Opeyemi E. Ayinde ${ }^{1 *}$, Tahirou Abdoulaye ${ }^{2}$, Olatunji Y. Ambali ${ }^{3}$, Grace O. Akinsola $^{3}$
}

\begin{abstract}
${ }^{I}$ Department of Agricultural Economics and Farm Management, University of Ilorin
${ }^{2}$ International Institute of Tropical Agriculture (IITA), Ibadan

${ }^{3}$ Department of Agricultural Economics and Extension Services, Kwara State University
\end{abstract}

Received $22^{\text {nd }}$ November 2016, Accepted $16^{\text {th }}$ November 2017

DOI: 10.2478/ast-2018-0002

*Corresponding author:

O.E. Ayinde, email: opeayinde@yahoo.com

Tel: +2348038309935

\begin{abstract}
The study was conducted to examine the determinants of quality protein maize (QPM) adoption among farming households in Niger State, Nigeria. A twostage random sampling procedure was employed to obtain data from selected 120 maize farming households. Descriptive statistics, logistic and tobit regression models were used for the analysis. Results of the analysis show that the awareness and adoption level of QPM production in the study area were 95\% and $87 \%$ respectively. Among the determinants of QPM adoption status, the coefficient of age $(-0.12734)$ and primary occupation $(-1.38295)$ of the respondents were negative and significant at $5 \%$ level of probability while the tenancy attribute's coefficient (2.62533) was positively significant at $10 \%$. The level of adoption of QPM was positively and significantly influenced by household size (0.00729) and years of schooling (0.01148) at $10 \%$ and $5 \%$ level of significant respectively. The study recommends intensification of information dissemination on the adoption of QPM in the study area.
\end{abstract}

Keywords: Determinants; Quality Protein; Maize; Adoption, farming household 


\subsection{Introduction}

The poverty and food crises in Africa reflect opportunities for technology innovations and transfer that should elicit new levels of cropping system intensity and diversity to mitigate the crises. The exploration of such technological opportunities involves, among other things, the development of high breed crops that have higher potential for sustainable economic benefits and optimal food production. One of such promising crops is Quality Protein Maize (QPM). QPM is an improved composite of intermediate maturity maize developed from a combination of first generation sib (S1) and half -sib recurrent selection with special traits of higher yield, improved cover, streak resistance, and hard endosperm modification as well as elevated levels of lysine and tryptophan (Ado et al., 2000). The nutritional component of QPM includes $10.7 \%$ protein, $76.2 \%$ carbohydrate, $7.0 \%$ moisture, $2.1 \%$ fat, $3.9 \%$ lysine and $1.1 \%$ tryptophan (Sofi et al., 2009). The crop has been found to be stable in grain -yield, tolerant to low nitrogen input and striga (Ado et al., 2000; Graham et al., 1990). Its higher level of fatty acid gives it an edge over other varieties of maize. Furthermore, QPM offers a considerable promise as a veritable weapon against poverty and food crises in Nigeria and Africa at large. Therefore, adoption of such crop among farmers will be of great assistance to the actualisation of food security in Nigeria. Ayinde et al. ((Ayinde et al., 2012) reported that the adoption of improved techniques in crop production can dramatically increase output thereby increasing the food security situation in the country.

Rogers (Rogers, 2003) posited that several factors influence the adoption of agricultural innovations. These include, among others, the need and want of farmers, their level of awareness and level of income. Emeson and Nwabu (Emeson and Nwabu, 2006) asserted that there is positive correlation between adoption of extension recommendations by farmers and crop yields which often translate into increased income and improved quality of life. In the same vein, Ayinde et al. (Ayinde et al., 2013) also reported that the higher yield of agricultural produce is greatly linked to the adoption of improved agricultural innovations by farmers. All things being equal, it is believed that the higher the relative advantage of a technology, the faster the rate of its adoption by the farmers, especially if the result of such technology is visible to the farmers.

So far, various QPM promotional activities like field demonstrations, field days, leaflets/brochures distribution and QPM seeds production have been conducted by Agricultural Research Institutes (ARIs) and experts in Africa since the inception of the QPM project in 2003. However, with all these promotion efforts, its adoption status has been observed to be low. Furthermore, there is little or no empirical information, to the researchers'knowledge, which can establish the factors behind such situation as far status of QPM technology adoption is concerned. Therefore, conducting a study on the factors that influence the adoption of QPM in Niger State, Nigeria becomes necessary.

\subsection{Materials and Methods}

The study was conducted in Niger state, Nigeria. Niger state is situated in the middle belt zone of Nigeria and lies within latitude $3^{\circ} 20 \mathrm{E}$ and longitude $8^{\circ}$ and $11^{\circ} 30 \mathrm{~N}$. To the North, Niger is bounded by Sokoto State, West by Kebbi State, in the South by Kogi State, in the South -West by Kwara State, in the North-East by Kaduna State and to the South-East by Federal Capital Territory, Abuja. As at 2006, the population of the state stood at 3,950, 249 people (Makama, 2010). Niger is endowed with ferruginous tropical soils which are suitable for mechanization as well as intensive cultivations of crops like roots and tubers, cereals, fruits and industrial tree crops, all which are the major crops grown in the state. Other Agricultural practices besides crop farming include livestock rearing (goats, cattle, sheep and poultry), hunting and fishing.

A two-stage sampling technique was employed to elicit data from respondents. In the first stage, Mokwa and Bida Local Government Areas of Niger State were purposively selected because of the prevalence of farmers who are beneficiaries and growers of the QPM seeds in the area. In stage two, 60 farmers were randomly selected each from Mokwa and Bida, giving a total of 120 farmers. The study made use of primary data obtained through the use of a well- structured questionnaire. Data were analysed by means of descriptive statistics such as frequency, percentage, logit and tobit regression models. The logistic regression analysis was utilized to examine the factors affecting farmers'perception on adoption of QPM (adoption status), while tobit regression model was used to analyse the determinants of the level of QPM adoption. The logit regression model is implicitly stated as:

$Y=f\left(x_{1}, x_{2}, x_{3}, x_{4}, x_{5}, x_{6}, x_{7}, x_{8}, x_{9}, x_{10}, x_{11}+u\right)$

Where $\mathrm{Y}=\mathrm{QPM}$ adoption status (Adopted $=1$, Not adopted $=0$ ); $\mathrm{x}_{1}=$ Farmers age (years);

$\mathrm{x}_{2}=\operatorname{Gender}($ male $=1$, female $=0)$;

$\mathrm{x}_{3}=$ Farmers education level (years);

$\mathrm{x}_{4}=$ Household size of farmers (persons);

$\mathrm{x}_{5}=$ Primary occupation $($ Farming $=1)$;

$\mathrm{x}_{6}=$ Maize farming experience of farmers (years);

$\mathrm{x}_{7}=$ Farm size of farmers (hectares);

$\mathrm{x}_{8}=$ Farm income (naira);

$\mathrm{x}_{9}=$ Tenancy status attribute (owned $=1,0$ otherwise);

$\mathrm{x}_{10}=$ Farmers access to credit (yes $=1$, no $=0$ );

$\mathrm{x}_{11}=$ Access to extension agent (yes $=1,0$ otherwise);

$\mathrm{u}=$ Error term

Also, the implicit tobit regression model for the adoption level is given as:

$\mathrm{Y}^{*}=\mathrm{f}\left(\mathrm{X}_{1}, \mathrm{X}_{2}, \mathrm{X}_{3}, \mathrm{X}_{4}, \mathrm{X}_{5}, \mathrm{X}_{6}, \mathrm{X}_{7}, \mathrm{X}_{8}, \mathrm{X}_{9}, \mathrm{X}_{10}, \mathrm{e}\right)$

Where $\mathrm{Y}^{*}=$ the intensity of QPM adoption (QPM adoption level) and $\mathrm{X}$ is as in equation 1 


\subsection{Results and Discussions}

The study reveals the socio-economic characteristics of respondents. It shows that majority $(86.7 \%)$ of the farmers were male indicating that male farmers adopted QPM than their female counterpart in the study area. The study also reveals that $76.5 \%$ of the respondents were found within the age bracket of $21-40$ years, $48 \%$ were married, $77 \%$ had at least primary school education, 95\% were QPM adopters and 68\% of these adopters claimed to strongly adopt the QPM. These imply that most of the respondents were young educated farmers who imbibed the adoption of new agricultural innovations. These findings concur with that of Nmadu et al. (2013) that observed that young farmers tend to be motivational, innovative and very adoptive.

Table 1 reveals the coefficients of determinants of QPM adoption status. According to Mwangi et al. (2013), the adoption status is the current use status of the technology after the farmer has full information about the technology, that is the farmer's decision to adopt the new technology or otherwise. The results indicate that the household age, household primary occupation and tenancy attribute of the farm land were found to be the only significant factors that determined the household head adoption status. The farmers'age was found to be negatively significant to the adoption status at 5\% statistical level. The negativity of the age coefficient implies that young farmers are more likely to adopt QPM than the older ones. In other word, the more the farmer advances in age, the lesser the tendency of adopting QPM, all things being equal. This observation disagrees with the evidence from previous studies by Ume et al. (Ume et al., 2005) and Onyenweaku et al. (Onyenweaku et al., 2007) who independently reported a positive significant relationship between age of farmers and adoption status in Anabra and Abia state respectively. The reason for disagreement may probably stems from regional factors.

That is, the adoption status of farmers in Niger state (Northern region) tends to be negatively significant with their age while that of their counterpart in Anambra and Abia state (Southern region) tends to be positively significant. Furthermore, the coefficient of primary occupation was also negative and statistically significant to the adoption status at $5 \%$ level of probability. This suggests that households that take farming as secondary occupation were more willing to adopt QPM than those having farming as their primary occupation. This implies that most full time farmers (farmers with farming as primary occupation) are high risk averters who prefer to stick to their old farming techniques probably because they may not have anything to fall back on in case of failure of the new techniques. The tenancy attribute of the farm land of household was found to be significant at $10 \%$ statistical level but having a positive relationship with the adoption status. The positive sign of the coefficient implies that households that own their farm land are more likely to adopt QPM than those that probably rent the land to use. This may be attributed to the fact that households having personal farm land are more likely to take risks and experiment new techniques on their farm since any loss, if at all, recorded will be limited to the farm output and no fear of incurring debt from land rent. Other factors examined such as gender, years of schooling, household size, access to credit, farm income, farm size, years of maize farming experience, and access to extension agents were not statistically significant to adoption status.

The Tobit regression estimates of the determinants of QPM adoption level among farmers in the study area are presented in Table 2. The study identified respondents'years of schooling, household size, farm land tenancy attribute, farm size and quantity of QPM harvested in the last agricultural season as the significant factors that determine the level at which households were willing to adopt QPM. The coefficient of schooling years of the household and household size was found to be positively and statistically significant to the adoption level at 5\% and $10 \%$ level of significance respectively. The positive sign of coefficient of schooling years implies that household heads that spent longer number of years in school have the tendency to adopt more than those that spent fewer years in formal education. In other words, the longer the number of years spent in school by the households, the higher the QPM adoption level, holding every other thing constant. This may be attributed to the fact that farmers with better education are likely to be more exposed to advancement in technology and as such be more willing to adopt any technological innovation that will improve their productivity. The positive significance of household size implies that farmers with larger households tend to be more willing to adopt than those with small household size. This may be due to the fact that larger households are usually characterized by more responsibilities in terms of adequate provision and sustenance of their family; therefore farmers with such huge family were willing to try any possible means of boosting their productivity so as to augment the sustenance and welfare of their household. This finding agrees with prior expectation that the larger the household size of a farmer, the more his willingness to adopt new technology (Ejechi et al., 2013).

\subsection{Conclusion and Recommendation}

Results from this study have shown that QPM farmers were young educated farmers who imbibed the adoption of new agricultural innovations. The adoption status of quality protein maize was significantly influenced by the household age, household primary occupation and tenancy attribute of the farm land at various level of probability while the adoption level was positively and significantly determined by years of schooling, household size, farm land tenancy attribute, farm size and quantity of QPM harvested in the last agricultural season. The study recommends further intensification of information dissemination on the adoption of QPM in the study area. 
Table 1: Logit Regression Estimates of Determinants of Farmers' Adoption Status of QPM

\begin{tabular}{|c|c|c|c|}
\hline Variable & Coefficient & $\begin{array}{l}\text { Standard } \\
\text { Error }\end{array}$ & t-value \\
\hline Age (years) & $-0.127^{* *}$ & 0.051 & -2.47 \\
\hline $\begin{aligned} \text { Gender }(1 & =\text { male, female } \\
& =0)\end{aligned}$ & -0.725 & 1.460 & -0.50 \\
\hline $\begin{array}{c}\text { Educational level (years of } \\
\text { Schooling ) }\end{array}$ & 0.054 & 0.140 & 0.39 \\
\hline Household Size (number) & 0.149 & 0.117 & 1.27 \\
\hline $\begin{array}{c}\text { Primary Occupation } \\
(1=\text { farming, others }=0)\end{array}$ & $-1.383^{* *}$ & 0.660 & -2.10 \\
\hline $\begin{array}{c}\text { Access to Credit (yes }=1, \\
\text { no }=0)\end{array}$ & -0.565 & 1.040 & -0.54 \\
\hline Farm income (Naira) & $4.65 \mathrm{e}-07$ & $2.99 \mathrm{e}-06$ & 0.16 \\
\hline $\begin{array}{l}\text { Tenancy Attribute (own } \\
=1 \text {, others }=0 \text { ) }\end{array}$ & $2.625^{*}$ & 1.48 & 1.77 \\
\hline Farm Size (hectares) & 0.027 & 0.181 & 0.15 \\
\hline $\begin{array}{c}\text { Maize Farming } \\
\text { Experience (years) }\end{array}$ & -0.244 & 0.154 & -1.57 \\
\hline $\begin{array}{l}\text { Access to Extension Agent } \\
\quad(\text { yes }=1, \text { no }=0)\end{array}$ & 1.21 & 0.920 & 1.30 \\
\hline Constant & $10.25^{* *}$ & 4.050 & 2.53 \\
\hline Log likelihood & -20.69 & & \\
\hline Chi-Square & $17.39^{*}$ & & \\
\hline
\end{tabular}

Source: Authors' Field Survey, 2014: * and ** are significant levels at $10 \%$ and $5 \%$ respectively.

\subsection{Conflict Of Interest}

All Authors have declared that there are no conflicts of interest.

\section{Authors Contribution}

OEA and TA designed the research

GOA data collection

OEA and GOA analysis of data

OEA and OYA discussion of result.
Table 2: Estimates of the Determinants of QPM Adoption Level

\begin{tabular}{|c|c|c|c|}
\hline Variable & Coefficient & $\begin{array}{l}\text { Standard } \\
\text { Error }\end{array}$ & t-value \\
\hline Age (years) & 0.00037 & 0.002 & 0.18 \\
\hline $\begin{array}{l}\text { Educational level (years of } \\
\text { Schooling ) }\end{array}$ & $0.01148^{* *}$ & 0.005 & 2.52 \\
\hline Household Size (number) & $0.007^{*}$ & 0.004 & 1.83 \\
\hline $\begin{array}{c}\text { Access to Credit (yes }=1, \\
\text { no }=0 \text { ) }\end{array}$ & -0.020 & 0.035 & -0.58 \\
\hline Farm income (Naira) & $-1.09 \mathrm{e}-07$ & $9.97 \mathrm{e}-08$ & -1.09 \\
\hline $\begin{array}{l}\text { Tenancy Attribute } \\
(\text { own }=1 \text {,others }=0)\end{array}$ & $0.128^{* * *}$ & 0.040 & 3.18 \\
\hline Farm Size (hectares) & $0.001^{* * *}$ & 0.002 & 2.69 \\
\hline Farm Experience (years) & 0.017 & 0.006 & 0.50 \\
\hline $\begin{array}{l}\text { Access to Extension Agent } \\
\quad(\text { yes }=1, \text { no }=0)\end{array}$ & 0.016 & 0.03545 & 0.45 \\
\hline $\begin{array}{l}\text { Quantity of harvested QPM } \\
\qquad(\mathrm{Kg})\end{array}$ & $0.0008^{* * *}$ & 0.0002 & 4.37 \\
\hline Constant & $0.273^{* * * *}$ & 0.094 & 2.92 \\
\hline Log likelihood & 45.53 & & \\
\hline Chi-Square & $42.23^{* * *}$ & & \\
\hline
\end{tabular}

Source: Authors' Field Survey, 2014; *, **, and *** are statistically significant at $10 \%, 5 \%$ and $1 \%$ respectively.

\section{References:}

Ayinde, O.E, Abduolaye T., Olaoye, G., Akangbe, J.A., 2013, Gender and Innovation in Agriculture: A Case Study of Farmers' Varietal Preference of Drought Tolerant Maize in Southern Guinea Savannah Region of Nigeria. Albanian J. Agric. Sci. (12) 4: 617-625.

Emeson, R.O., Nwabu, G. 2006. Extension on FarmYields in KenyaCenter. Discussion paper No.798. (Yale, Economic Growth Centre, Yale University).

Graham, G.G., Lembcke, J., Morales, E., 1990, Quality-protein maize as the sole source of dietary protein and fat for rapidly growing young children. Pediatrics 85, 85-91.

Makama, S.D. 2010. 2006 Population and Housing Census, Priority table, NPC, ed. (Abuja, Federal Republic of Nigeria), p. 64. 
Mwangi M., Kariuki S., 2015, Factors Determining Adoption of New Agricultural Technology by Smallholder Farmers in Developing Countries. Journal of Economics and Sustainable Development 6 (5): 208-216

Nmadu, J. N. Sallawu, H., \& Omojeso B. V., 2015, Socio-Economic Factors Affecting Adoption of Innovations by Cocoa Farmers in Ondo State, Nigeria. European Journal of Business, Economics and Accountancy 3(2): 58-66.

Onyenweaku, C., Okoye, B., Okorie, K., 2007, Determinants of fertilizer adoption by rice farmers in Bende Local Government Area of Abia State, Nigeria.

Rogers, E.M., 2003, Diffusion of innovations. Free Press. New York, 551.

Sofi, P., Wani, S.A., Rather, A., Wani, S.H., 2009, Quality protein maize (QPM): genetic manipulation for the nutritional fortification of maize. Journal of Plant Breeding and Crop Science 1, 244253. 